\title{
Leaf application of chitosan and physiological evaluation of maize hybrids contrasting for drought tolerance under water restriction
}

\author{
V. Veroneze-Júnior ${ }^{a}$ (D), M. Martins ${ }^{a}$ (D), L. Mc Leod ${ }^{b}$ (D), K. R. D. Souza ${ }^{a}$ (D), \\ P. R. Santos-Filho ${ }^{\text {(D), P. C. Magalhães (D), D. T. } \text { Carvalho }^{d} \text { (D), M. H. Santos }}{ }^{\text {(D) }}$ \\ and T. C. Souza ${ }^{a *}$ (D) \\ anstituto de Ciências da Natureza, Universidade Federal de Alfenas - UNIFAL-MG, R. Gabriel Monteiro da Silva, 700, \\ CEP 37130-001, Alfenas, MG, Brasil

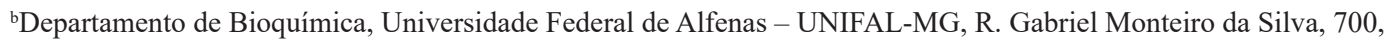 \\ CEP 37130-001, Alfenas MG, Brasil \\ 'Embrapa Milho e Sorgo, MG 424 Road Km 45, Sete Lagoas, MG, Brasil \\ dFaculdade de Ciências Farmacêuticas, Universidade Federal de Alfenas - UNIFAL-MG, R. Gabriel Monteiro da Silva, \\ 700, CEP 37130-001, Alfenas MG, Brasil \\ 'Departamento de Química, Universidade Federal de Viçosa - UFV, Peter Henry Rolfs, CEP 36570-000, Viçosa, MG, Brasil \\ *e-mail: thiagonepre@hotmail.com
}

Received: January 8, 2019 - Accepted: May 6, 2019 - Distributed: August 31, 2020

(With 3 figures)

\begin{abstract}
It is a fact that the regions that cultivate the most maize crop do not have fully adequate technologies to measure productivity losses caused by irregularities in water availability. The objective of this study was to evaluate the physiological characteristics of maize hybrids tolerant (DKB 390) and sensitive (BRS 1030) to drought, at V5 growth stage and under water restriction, in order to understand the mechanisms involved in the induction of tolerance to drought by chitosan in contrasting maize genotypes. Plants were cultivated in pots at a greenhouse, and chitosan $100 \mathrm{ppm}$ was applied by leaf spraying. The water restriction was imposed for 10 days and then leaf gaseous exchange and chlorophyll fluorescence were evaluated. The tolerant hybrid (DKB 390) showed higher photosynthesis, stomatal conductance, carboxylation efficiency, electron transport rate, and non-photochemical quenching when chitosan was used. Plants from tolerant genotype treated with chitosan were more tolerant to water stress because there were more responsive to the biopolymer.
\end{abstract}

Keywords: water stress, gaseous exchange, quenching, chlorophyll fluorescence, Zea mays L.

\section{Aplicação foliar de quitosana e avaliação fisiológica de híbridos de milho contrastantes para tolerância à seca sob restrição hídrica}

\section{Resumo}

As regiões que cultivam milho como cultura principal ainda não possuem tecnologias adequadas para mensurar as perdas na produtividade decorrentes na disponibilidade irregular de água. O objetivo desse estudo foi avaliar as características fisiológicas de híbridos de milho tolerante (DKB 390) e sensível (BRS1030) à seca, no estádio de crescimento V5 e sob restrição hídrica, para compreender os mecanismos envolvidos na indução de tolerância à seca pela quitosana em genótipos contrastantes. As plantas foram cultivadas vasos na casa de vegetação e a quitosana 100 ppm foi aplicada por pulverização foliar. A restrição hídrica durou 10 dias e foram avaliadas as trocas gasosas e a fluorescência da clorofila. O híbrido tolerante (DKB 390) apresentou maior fotossíntese, condutância estomática, eficiência de carboxilação, taxa de transporte de elétrons e quenching não fotoquímico quando aplicada a quitosana. As plantas do genótipo tolerante tratadas com quitosana foram mais tolerantes ao déficit hídrico porque foram mais responsivas ao biopolímero.

Palavras-chave: estresse hídrico, trocas gasosas, quenching, fluorescência da clorofila, Zea mays L.

\section{Introduction}

One of the major abiotic stresses in plants is the water restriction (drought) due to the lack of rainfall, which has caused great losses in world agriculture (FAO, 2002; Filippou et al.,
2013). In the world as well as in Brazil, the main maize production regions do not have adequate technologies to mitigate losses in productivity and are depending on the climate. 
The characterization of products and resources that lead to drought tolerance in plants is essential to the world agriculture. For a plant species, as maize, to survive in adverse situations such as drought, three alternatives can be used to maintain growth and productivity. The first is the classical breeding, that involves the sexual crossbreeding between plants of the same species or other closely related containing the characteristics of interest, such as drought tolerance (Beyene et al., 2016). The second strategy of plant breeding is based on transgenic techniques, for instance obtaining transgenic maize with improved drought tolerance (Nuccio, 2018). A third alternative, explored by this work, is the treatment with several molecules to mitigate the effects of stress in the plant. For this purpose, the application of several biostimulants is carried out (in soil or via leaf spraying) and then evaluations are performed in order to verify if was an improvement of the plant submitted to the drought (Souza et al., 2013b; Jardin, 2015; Pichyangkura and Chadchawan, 2015; Shafiq et al., 2015).

Chitosan is a biopolymer of low toxicity and easy to obtain that has been explored in medicine, pharmacy and in agriculture (Kaur and Dhillon, 2014; Zargar et al., 2015). Chitosan is a deacetylated chitin derivative structurally similar with units of $\mathrm{N}$-acetylglucosamine and glycosamine. The deacetylated biopolymer must contain a percentage of deacetylation (DDA) between 40 and $98 \%$ to be considered chitosan (Zargar et al., 2015).

The role of chitosan on the defense against phytopathogens (Hadwiger, 2015) and promoting the growth and development of plants under abiotic stresses, such as drought, through the induction of stress indicators and antioxidant system, besides the decrease of leaf transpiration (Iriti et al., 2009; Pongprayoon et al., 2013) has been demonstrated.

Also, the leaf application of chitosan in maize genotypes showed higher germination, plant height, leaf number, leaf area, biomass characteristics and grain yield (Lizárraga-Paulín et al., 2011). However, few studies focused on physiological characteristics such as leaf gaseous exchange and chlorophyll fluorescence (Martins et al., 2018). The genotype, growth stage, time of application, concentration and composition of biopolymers must be considered for improving plant responses to these molecules (Dutta et al., 2004; Zargar et al., 2015; Souza et al., 2016). Thus, despite the induction of drought tolerance in maize by chitosan, drought-resistant genotypes may respond differently to chitosan application, as observed for other substances (Ali and Ashraf, 2011; Souza et al., 2013a).

Drought is limiting in three stages of maize cycle: V5, with five fully expanded leaves; VT, at tasseling; and R3 during grain filling. The drought occurrence in the initial V 5 can reduces the productive potential since floral differentiation occurs at this phase (Magalhães and Durães, 2008; Souza et al., 2016; Yan et al., 2016). Nevertheless, in a scenario of climate change, the irregular water availability for the plants in the initial stages of development becomes increasingly evident, with dry periods in rainy seasons. Thus, the objective of the present study was to evaluate the physiological characteristics of two maize hybrids contrasting for drought tolerance at V 5 growth stage under water restriction, after application of chitosan, in order to understand the mechanisms involved in the induction of drought tolerance in maize by chitosan.

\section{Material and Methods}

\subsection{Plant Material and growth conditions}

Two maize (Zea mays L.) hybrids with contrasting drought tolerance were used: DKB 390 (tolerant) from Dekalb and BRS 1030 (sensitive) from the Embrapa Breeding Program (Souza et al., 2013a, 2016). The experiment was conducted in a greenhouse of the Federal University of Alfenas, located in Alfenas, MG (altitude $818 \mathrm{~m}$, latitude $21^{\circ} 25^{\prime}$ 'South, longitude $45^{\circ} 58^{\prime}$ ' West). The average values for global radiation, temperature and air humidity observed during the evaluation period are shown in the supplementary material (Figure S1 and S2).

The experiment was carried out in 14 liters pots containing a very clayey Oxisol. Four seeds were sowed per pot but only one plant remained after thinning. The chemical analysis of the soil is shown in Table S1 (supplementary material). Soil preparation was proposed according to the needs of soil and crop (600 kg ha-1 of 8-28-16 $\mathrm{NP}_{2} \mathrm{O}_{5}-\mathrm{K}_{2}$ plus $\mathrm{Zn}$ ) fertilizer. Regular irrigation was accomplished in order to maintain optimal soil moisture until the imposition of the water restriction.

\subsection{Imposition of water restriction, chitosan application and experimental design}

The beginning of the water restriction was around three fully expanded leaves (V3) growth stage. The water was gradually restricted until plants reached V5 growth stage, when they were definitively stressed (first day of stress). During the experimental time the analyzes were performed at $7^{\text {th }}, 8^{\text {th }}, 9^{\text {th }}$ and $10^{\text {th }}$ days of water stress.

Pre-dawn water potential $\left(\Psi_{\mathrm{pd}}\right)$ was used to evaluate the water restriction (stress). As the soil water potential indicates the water content of the plant and the soil (equilibrium) (Bergonci et al., 2000), all the measurements were taken from the moment when the water potential of the stressed treatments differed from the irrigated, that is, on the seventh day. Water restriction lasted 10 days and the irrigated treatments received daily watering until the end of the experiment.

Chitosan was applied at three times: at the beginning of the water stress (first day), in the fifth and seventh days after imposition of water stress, when started the evaluations. The chitosan used (Galena química e Farmacêutica Ltda.) contains $63.5 \%$ of deacetylation and dynamic viscosity of $18.5 \mathrm{mPa} . \mathrm{s}$, at the concentration of $0.5 \%(\mathrm{w} / \mathrm{v})$. Further details on the physico-chemical characteristics of chitosan can be found in Martins et al., (2018). The chitosan at 100 ppm (Mondal et al., 2013) was 
applied to the canopy of the plants, dissolved in acidified water to $\mathrm{pH}$ 6.5. The application was performed with a pressure hand sprayer in the dosage of $25 \mathrm{~mL}_{\text {plant }}{ }^{-1}$.

A randomized block design was used with six replications (one plant per pot), two hybrids (BRS 1030 and DKB 390) and four treatments. These treatments were: (irrigated without application of chitosan (Irrigated); with water restriction and without chitosan application (Stressed); with water restriction and application of chitosan (Stressed + Chitosan) and with water restriction and with application of the solution used to dissolve the chitosan in water ( Stressed $+\mathrm{H}_{2} \mathrm{O}$ ). There was no treatment irrigated + chitosan since previous experiments showed no difference compared to the irrigated treatments (data not shown).

\subsection{Leaf measurements of pre-dawn water potential, gaseous exchange and chlorophyll fuorescence}

The pre-dawn water potential (pre-dawn, $\Psi_{\text {pd }}$ ) was determined before dawn $(5 \mathrm{am})$ using a Scholander type pressure chamber (Soil Moisture Equipment Corp., Model SEC-3015G2, Santa Barbara CA, USA) in four fully expanded leaves (four replications).

Measurements of gaseous exchange were performed through a portable photosynthesis system (IRGA, Model LI-6400 XT, Li-Cor, Lincoln, Nebraska, USA). All measurements were performed in the morning between 8:00 and 10:00, on the last fully expanded leaf (V5 leaf). The variables evaluated were photosynthetic rate $(\mathrm{Pn})$, stomatal conductance (gs) and carboxylation efficiency (photosynthesis and intercellular $\mathrm{CO}_{2}$ concentration ratio, $\mathrm{Pn} / \mathrm{Ci}$ ). The measurements were done in a leaf area of $6 \mathrm{~cm}^{2}$, with $\mathrm{CO}_{2}$ flow controlled in the concentration of $380 \mu \mathrm{mol} \mathrm{CO}_{2} \mathrm{~mol}^{-1}$ air. The photon flux density (PPFD) was $1500 \mu \mathrm{mol} \mathrm{m}^{-2} \mathrm{~s}^{-1}$ with blue-red LED light source (6400-02B LED) and controlled leaf temperature $\left(30^{\circ} \mathrm{C}\right)$.

A Mini-PAM modulated fluorimeter (Heinz Walz, Effeltrich, Germany) was used for the measurement of chlorophyll fluorescence parameters. The leaves remained in the dark and after an adaptation period of 30 minutes the minimum fluorescence ( $\mathrm{Fo}$ ) was measured with a light sufficiently low to avoiding photochemical reactions and maximum fluorescence ( $\mathrm{Fm}$ ), applying for 0.8 seconds a saturating light pulse of $7000 \mu \mathrm{m}$ of $\mathrm{m}^{-2} \mathrm{~s}^{-1}$ photons. In the samples adapted to the dark, the maximum efficiency of the photosystem (PSII) was estimated by the $\mathrm{Fv} / \mathrm{Fm}$ ratio. The leaves were then illuminated with actinic light with an intensity of $1500 \mu \mathrm{mol}$ of photons $\mathrm{m}^{-2} \mathrm{~s}^{-1}$. Subsequently the constant fluorescence (Fs) was obtained and then another pulse of saturating light was applied for $1 \mathrm{~s}$ to obtain the maximum fluorescence emitted by the leaves (Fm'). The actinic light was removed and the leaves were irradiated with distant red light to obtain light-adapted Fo (Fo'). Photochemical quenching was calculated as $\mathrm{qP}=\left(\mathrm{Fm} \mathrm{H}^{\prime}-\mathrm{Fs}\right) /\left(\mathrm{Fm}^{\prime}-\mathrm{Fo}^{\prime}\right)$, and non-photochemical quenching was calculated as $\mathrm{NPQ}=(\mathrm{Fm}-\mathrm{Fm}$ ' $) / \mathrm{Fm}$ '. Other parameters were also evaluated, such as electron transport rate $(E T R)=[(F m$ '-Fs $/$ Fm ' $) \times$ PPFD x $0.5 \times 0.84$; Effective

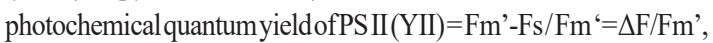
quantum yields of regulated energy dissipation of $\mathrm{PSII}, \mathrm{YNPQ}=\mathrm{Fs} / \mathrm{Fm}$ '-Fs $/ \mathrm{Fm}$, quantum yields of non-regulated energy dissipation of PSII, YNO = Fs / Fm (Van Kooten and Snel, 1990; Genty et al., 1996).

\subsection{Data analysis}

Means and standard errors (SE) were calculated for each parameter in the days under water deficit (7, 8, 9 and 10). Statistical analysis of the results compared treatments and hybrids in each day of water stress, and analysis of variance (ANAVA) and the Scott-Knott averages comparison test were used at $0.05 \%$ significance level $(p \leq 0.05)$, in the Sisvar version 4.3 (Federal University of Lavras, Lavras, Brazil).

\section{Results}

Values of water potential up to - $0.75 \mathrm{MPa}$ were observed for maize genotypes under water deficit (Figure 1a). The application of chitosan did not cause differences in water potential of the drought-sensitive hybrid (BRS 1030) compared to the stressed treatment (Figure 1a). In the ninth and tenth days of water deficit the chitosan application in the drought tolerant hybrid (DKB 390) resulted in a higher water status compared to the stressed treatment not receiving chitosan or the irrigated (Figure 1a). In addition, the stressed chitosan-treated DKB 390 presented significantly higher average mean than BRS 1030 at the same condition.

The application of chitosan in the BRS 1030 after nine days of water restriction resulted in higher photosynthesis (Pn) (Figure 1b), but did not result in greater stomatal conductance (gs) (Figure 1c). This higher photosynthetic rate may be connected to the higher efficiency of carboxylation $(\mathrm{Pn} / \mathrm{Ci})$ as evidenced in Fig 1D. The application of chitosan in the drought-tolerant hybrid (DKB 390) provided higher photosynthetic rate (Pn) (Figure 1b), stomatal conductance (gs) (Figure 1c) and carboxylation efficiency $(\mathrm{Pn} / \mathrm{Ci}$ ) (Figure 1d) at the end of stress (at 10 days for $\mathrm{Pn}$ and $\mathrm{gs}$ and almost all water restriction period for $\mathrm{Pn} / \mathrm{Ci}$ ).

The values of electron transport rate (ETR) were reduced in BRS1030 under water deficit (stressed) but the application of chitosan did not cause significant difference (Figure 2a). On the other hand, plants of DKB 390 that received chitosan (ninth and tenth day of restriction) showed higher ETR. The tolerant hybrid (DKB 390) presented higher ETR than the sensitive one (BRS 1030) at the 10 days of restriction (Figure 2a).

In this study, qP and YII decreased with water restriction compared to the irrigated treatment, but there was no difference between the treatments stressed with and without application of chitosan for both BRS 1030 and DKB 390 (Figure 2b, c). For BRS 1030 water restriction (stressed) resulted in greater non-photochemical dissipation (NPQ) when compared to irrigated plants, but there were no significant differences with chitosan application (Figure 2d). 

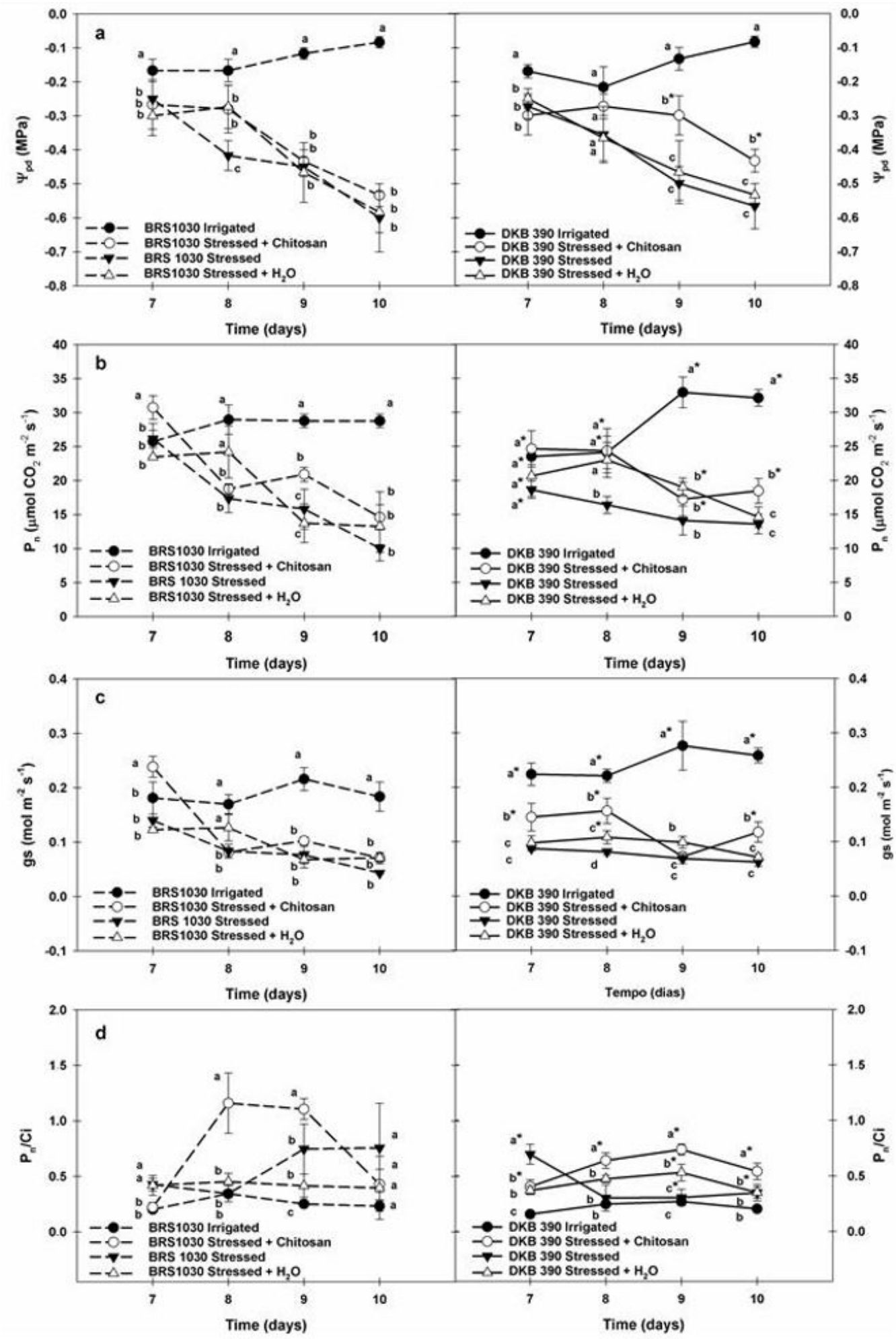

Figure 1. Pre-dawn leaf water potential $\left(\Psi_{\mathrm{pd}}\right)(\mathrm{a})$ and gaseous exchange parameters during the period of 10 days of water restriction in two maize hybrids, with and without the application of chitosan. Photosynthetic rate (Pn) (b), Stomatal conductance (gs) (c) and carboxylation efficiency (Pn/Ci) (d). On the left are the data of the drought susceptible hybrid BRS 1030 and on the right the data of the drought tolerant hybrid DKB 390. Means followed by the same letter between the treatments in each day of water restriction $(7,8,9$ and 10$)$ do not differ by Scott-Knott test at $5 \%$ probability $(p \leq 0.05)$. * indicates difference between hybrids in treatment and day of water restriction. Bars correspond to \pm standard error $(\mathrm{SE})(\mathrm{n}=6)$. 

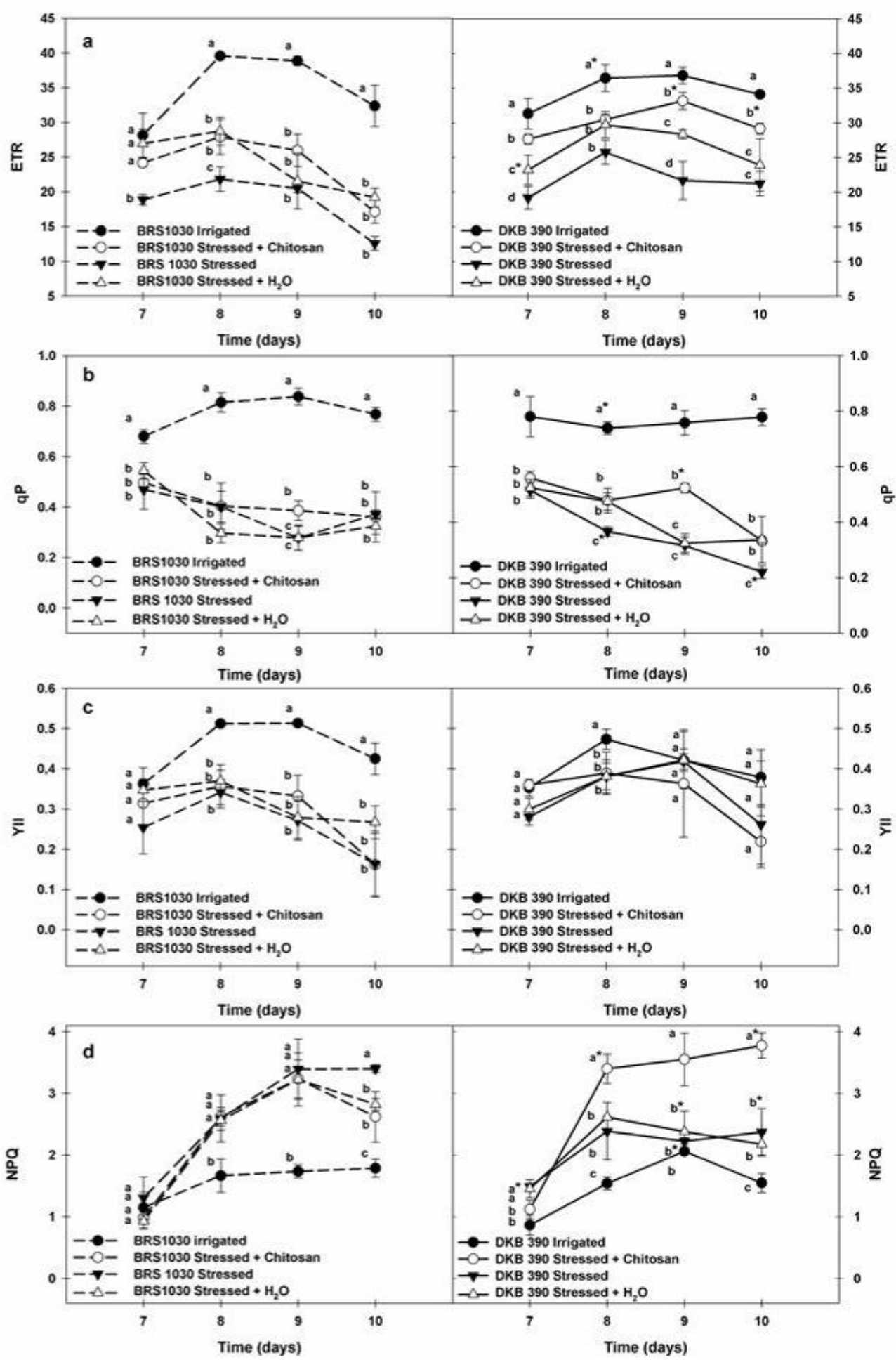

Figure 2. Chlorophyll fluorescence parameters during the period of 10 days of water restriction in two maize hybrids, with and without the application of chitosan. Electron transport rate (ETR) (a), photochemical quenching (qP) (b), Effective photochemical quantum yield of PSII (YII) (c), non-photochemical quenching (NPQ) (d). On the left are the data of the drought susceptible hybrid BRS 1030 and on the right the data of the drought tolerant hybrid DKB 390. Means followed by the same letter between the treatments in each day of water restriction (7, 8, 9 and 10) do not differ by Scott-Knott test at $5 \%$ probability $(\mathrm{p} \leq 0.05)$ * indicates difference between hybrids in treatment and day of water restriction. Bars correspond to \pm standard error $(\mathrm{SE})(\mathrm{n}=6)$. 
Differently, for DKB 390 the stressed treatment + Chitosan presented higher NPQ at 8,9 and 10 days of water deficit. Among the hybrids, the tolerant presented higher NPQ than the sensitive at 7 and 10 days of restriction (Figure 2d).

Significant differences between treatments of BRS1030 were observed for quantum yields of non-regulated energy dissipation of PSII (YNO) for the irrigated treatments with lower means, followed by stress $+\mathrm{H}_{2} \mathrm{O}$ (Figure $3 \mathrm{a}$ ).
DKB 390 presented lower YNO means compared to BRS 1030 without differences between treatments. No differences occurred between treatments regarding the quantum yields of regulated energy dissipation of PSII (YNPQ) in BRS 1030, except for irrigated (Figure 3b). For the DKB 390, an increase of YNPQ was observed in the stressed treatment, especially in the stressed with chitosan at the 9 and 10 days of restriction.

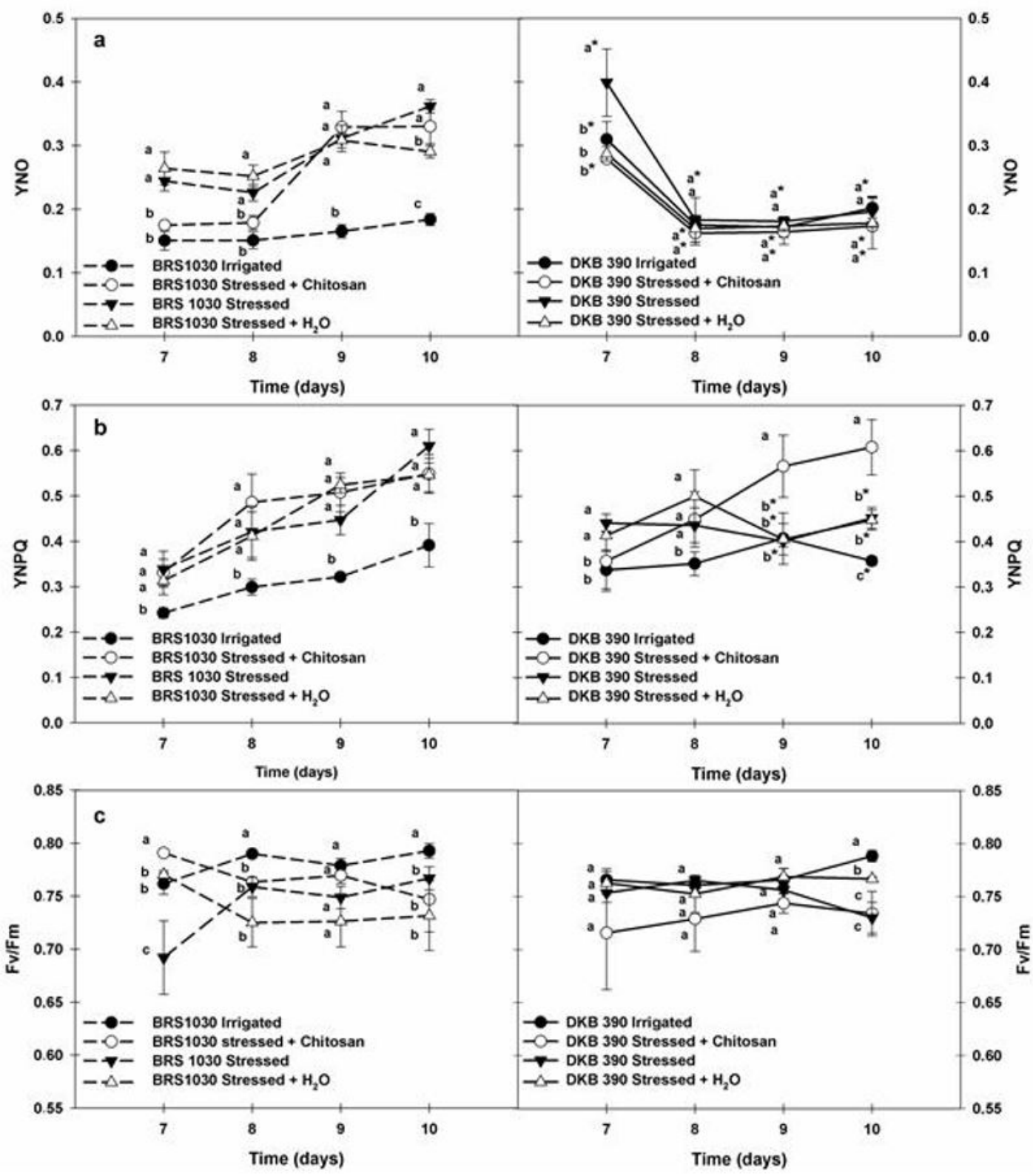

Figure 3. Chlorophyll fluorescence parameters during the period of 10 days of water restriction in two maize hybrids, with and without the application of chitosan. Quantum yields of non-regulated energy dissipation of PSII (YNO) (a), quantum yields of regulated energy dissipation of PSII (YNPQ) (b), maximum quantum efficiency of PSII (Fv / Fm) (c). On the left are the data of the drought susceptible hybrid BRS 1030 and on the right the data of the drought tolerant hybrid DKB 390. Means followed by the same letter between the treatments in each day of water restriction $(7,8,9$ and 10) do not differ by Scott-Knott test at $5 \%$ probability $(\mathrm{p} \leq 0.05) . *$ indicates difference between hybrids in treatment and day of water restriction. Bars correspond to \pm standard error $(\mathrm{SE})(\mathrm{n}=6)$. 


\section{Discussion}

The values of water potential observed in maize genotypes under water deficit (-0.75 $\mathrm{MPa})$ indicate mild to moderate stress (Bergonci et al., 2000; Barnaby et al., 2013). In addition, the stressed chitosan-treated DKB 390 showed significantly higher average mean than BRS 1030 at the same condition. Souza et al. (2016) evaluated these two maize hybrids under water stress and observed that the BRS 1030 sensitive hybrid had a more advantageous root system for water absorption (volume, root length) at V5 stage than the tolerant hybrid DKB 390. In advanced stages an inversion of root architecture occurred among hybrids. Although the root system was considered an important character to maintain a better water status in the plant, the BRS 1030 did not stand out even with the application of the biopolymer.

Drought causes stomatal and non-stomatal (biochemical) limitations in maize. The first one is related to the opening and closing of the stomata and the second is connected to aspects of energy dissipation in the first photosynthetic stage (photochemistry) and the inhibition of enzymes of the second phase (Calvin cycle) such as Rubisco (Souza et al., 2014; Prado et al., 2018). Apparently, chitosan acted differently in drought-tolerant hybrids. In BRS 1030, chitosan increased Pn only due to the reduction of non-stomatal limitation (higher Pn/Ci) and in DKB 390 increased Pn because induced greater stomatal conductance under drought, that is, by decreasing stomatal limitation, and also for reducing the non-stomatal limitation. This action of chitosan, that decreases the two limitations in maize under drought, could explain higher Pn and gs in the hybrid DKB 390 compared to BRS 1030 at the end of the stress (Figure 1b, c).

Increase of photosynthesis and stomatal conductance was also observed by Khan et al. (2002) by applying chitosan in soybean and maize. Genetic variability for drought tolerance was found in maize with higher photosynthesis (Pn) and stomatal conductance (gs) under water deficit (Carvalho et al., 2011; Souza et al., 2013b). Chamnanmanoontham et al. (2015) showed that chitosan can induces the action of genes from nucleus and chloroplast involved in the increase of the photosynthesis.

Some divergences or different mechanisms of tolerance in maize concerning these physiological characteristics are found in the literature. In one approach, genotypes are more efficient in saving water by fixed carbon, thus maintaining water status (Water Use Efficiency). Alternatively, some genotypes can maintain the water status by escaping from stress (deeper roots, for example), keeping the stomata more open and maintaining photosynthesis, that is, they spend more water (Water Use) (Blum 2009; Avila et al., 2017). The higher gaseous exchanges and water status found in the genotypes evaluated in the present study (mainly DKB 390) show that these plants may have greater tolerance to drought when chitosan is applied, mainly due to the better water use (WU) and not to the greater water use efficiency (WUE). The genotype DKB 390 that received the biopolymer was more able to found and to spend water because even under drought maintained the stomatal opening. Some authors reported that a higher water status may favors a greater stomatal conductance causing a $\mathrm{CO}_{2}$ flow and also a leaf cooling (canopy) by transpiration in plants under water stress.

Ahmad et al. (2017) and Zhang et al. (2016) suggested that oligomers of chitosan can affect the efficiency of light use because these molecules induce positive modifications in chlorophyll fluorescence. Drought-tolerant maize genotypes tend to have higher electron transport rate (ETR), photochemical quenching (qP), and effective photochemical quantum yield of PS II (YII) (Souza et al., 2013b; Saglam et al., 2014). The increase of the ETR in DKB 390 with chitosan application indicates higher electron flux and greater energy to dissipate under drought that seems to have been changed for both photosynthesis and non-photochemical dissipation.

As the drought prevents the use of ATP and NADPH due to the inhibition of the enzymes of the Calvin cycle and thus causing an accumulation of electrons/energy in the photosystems, the tolerant genotypes have an adaptation in the dissipation of this energy: increased non-photochemical quenching (NPQ) (Souza et al., 2013b). NPQ is involved in the dissipation of excess energy (photons) and in the regulation of the reaction center of photosystem II, being a mechanism of photoprotection (Yan et al., 2017). This ability to dissipate excess electrons and to protect the photosystems is well evidenced in the analysis of the NPQ partitioning. Tolerant genotypes tend to present more regulated non-photochemical quenching (YNPQ), in other words, quantum yields of regulated energy dissipation of PSII than non-photochemical non-regulated quenching (YNO). This causes the release of energy to enzymatic reactions, heat and not to the reactive oxygen species (ROS) (Reis et al., 2018). Chitosan, consequently, increases this behavior in the early stages of the tolerant genotype (DKB 390).

The maximum efficiency of the photosystem (PSII) $(\mathrm{Fv} / \mathrm{Fm})$ in the irrigated treatment was higher among the BRS 1030 treatments and did not differ among the other treatments (Figure 3c). Concerning Fv/Fm between treatments of DKB390, the highest value was observed in the irrigated, followed by the stressed and the other treatments. However, none of the two hybrids showed values of Fv/Fm lower than 0.75 (except BRS1030 stressed) indicating intense photoinhibition (Kalaji and Guo, 2008). Although one of the most used fluorescence parameters is $\mathrm{Fv} / \mathrm{Fm}$, it has been observed in some cases, as in maize, that $\mathrm{Fv} / \mathrm{Fm}$ is not a responsive parameter to stress under severe water deficit conditions (Brestic and Zivcak, 2013; Souza et al., 2013b; Yan et al., 2016).

Finally, in this study the tolerant genotype (DKB 390) at V5 stage showed greater changes in leaf gaseous exchange and chlorophyll fluorescence when chitosan was pulverized in leaves and was more receptive to the biopolymer. As hypothesis, this best response could be connected to the best biopolymer-leaf receptor binding in this hybrid, which when receives the chitosan cleaves it in chitosan 
oligomers that diffuses to the cell acting in specific sites (Chamnanmanoontham et al., 2015; Pichyangkura and Chadchawan, 2015; Malerba and Cerana, 2016).

\section{Acknowledgements}

The authors would like to thank the Fundação de Amparo à Pesquisa do Estado de Minas Gerais (FAPEMIG) and Universidade Federal de Alfenas (UNIFAL-MG) for scientific initiation scholarship of V. Veroneze-Júnior. The authors also thank the Conselho Nacional de Desenvolvimento Científico e Tecnológico (CNPq) and FAPEMIG for the financial support to the research project (APQ-00651-14); and the Coordenação de Aperfeiçoamento de Pessoal de Nível Superior (CAPES) for the post-doctoral researcher PNPD-institutional scholarship of K.R.D. Souza (Funding Code 001).

\section{References}

AHMAD, B., KHAN, M.M.A., JALEEL, H., SADIQ, Y., SHABBIR, A. and UDDIN, M., 2017. Exogenously sourced $\gamma$-irradiated chitosan-mediated regulation of growth, physiology, quality attributes, and yield in Mentha piperita L. Turkish Journal of Biology, vol. 41, no. 2, pp. 388-401. http://dx.doi.org/10.3906/ biy-1608-64.

ALI, Q. and ASHRAF, M., 2011. Induction of drought tolerance in maize (Zea mays L.) due to exogenous application of trehalose: growth, photosynthesis, water relations and oxidative defense mechanism. Journal Agronomy \& Crop Science, vol. 197, no. 4, pp. 258-271. http://dx.doi.org/10.1111/j.1439-037X.2010.00463.x.

AVILA, R., MAGAlHÃES, P.C., DE ALVARENGA, A.A., LAVINSKY, A.D.O., CAMPOS, C.N., GOMES JÚNIOR, C.C. and DE SOUZA, T.C., 2017. Drought-tolerant maize genotypes invest in root system and maintain high harvest index during water stress. Revista Brasileira de Milho e Sorgo, vol. 15, no. 3, pp. 450460. http://dx.doi.org/10.18512/1980-6477/rbms.v15n3p450-460.

BARNABY, J.Y., KIM, M., BAUCHAN, G., BUNCE, J., REDDY, V. and SICHER, R.C., 2013. Drought responses of foliar metabolites in three maize hybrids differing in water stress tolerance. PLoS One, vol. 8, no. 10, pp. e77145. http://dx.doi.org/10.1371/ journal.pone.0077145. PMid:24143208.

BERGONCI, J.I., BERGAMASCHI, H., BERLATO, M.A. and SANTOS, A.O., 2000. Leaf water potential as an indicator of water deficit in maize. Pesquisa Agropecuária Brasileira, vol. 35, no. 8, pp. 1531-1540. http://dx.doi.org/10.1590/S0100-204X2000000800005.

BEYENE, Y., SEMAGN, K., CROSSA, J., MUGO, S., ATLIN, G.N., TAREKEGNE, A., MEISEL, B., SEHABIAGUE, P., VIVEK, B.S., OIKEH, S., ALVARADO, G., MACHIDA, L., OLSEN, M., PRASANNA, B.M. and BÄNZIGER, M., 2016. Improving maize grain yield under drought stress and non-stress environments in Sub Saharan Africa using marker-assisted recurrent selection. Crop Science, vol. 56, no. 1, pp. 344-353. http://dx.doi. org/10.2135/cropsci2015.02.0135.

BLUM, A., 2009. Effective use of water (EUW) and not water-use efficiency (WUE) is the target of crop yield improvement under drought stress. Field Crops Research, vol. 112, no. 2-3, pp. 119123. http://dx.doi.org/10.1016/j.fcr.2009.03.009.
BRESTIC, M. and ZIVCAK, M., 2013. PSII fluorescence techniques for measurement of drought and high temperature stress signal in crop plants: protocols and applications. In: G.R. ROUT and A.B. DAS. Molecular stress physiology of plants. India: Springer, pp. 87-131. http://dx.doi.org/10.1007/978-81-322-0807-5_4.

CARVAlHO, R.C., CUNHA, A. and SILVA, J.M., 2011. Photosynthesis by six Portuguese maize during drought stress and recovery. Acta Physiologiae Plantarum, vol. 33, no. 2, pp. 359-374. http://dx.doi.org/10.1007/s11738-010-0555-1.

CHAMNANMANOONTHAM, N., PONGPRAYOON, W., PICHAYANGKURA, R., ROYTRAKUL, S. and CHADCHAWAN, S., 2015. Chitosan enhances rice seedling growth via gene expression network between nucleus and chloroplast. Plant Growth Regulation, vol. 75, no. 1, pp. 101-114. http://dx.doi.org/10.1007/ s10725-014-9935-7.

DUTTA, P.K., DUTTA, J. and TRIPATHI, V.S., 2004. Chitin and chitosan: chemistry, properties and applications. Journal of Scientific and Industrial Research, vol. 63, pp. 20-31.

FILIPPOU, P., ANTONIOU, C. and FOTOPOULOS, V., 2013. The nitric oxide donor sodium nitroprusside regulates polyamine and proline metabolism in leaves of Medicago truncatula plants. Free Radical Biology \& Medicine, vol. 56, no. 1, pp. 172-183. http:// dx.doi.org/10.1016/j.freeradbiomed.2012.09.037. PMid:23041351.

FOOD AND AGRICULTURE ORGANIZATION OF THE UNITED NATIONS - FAO, 2002. Deficit irrigation practices. Rome: FAO. Water Reports, no. 22.

GENTY, B., HARBINSON, J., CAILLY, A.L. and RIZZA, F., 1996. Fate of excitation at PS II in leaves: the non- photochemical side. In: Proceedings of the III BBSRC Robert Hill Symposium on Photosynthesis, 1996, Western Bank. Western Bank: University of Sheffield.

HADWIGER, L.A., 2015. Anatomy of a nonhost disease resistance response of pea to Fusarium solani: PR gene elicitation via DNase, chitosan and chromatin alterations. Frontiers of Plant Science, vol. 6, pp. 373. http://dx.doi.org/10.3389/fpls.2015.00373. PMid:26124762.

IRITI, M., PICCHI, V., ROSSONI, M., GOMARASCA, S., LUDWIG, N., GARGANO, M. and FAORO, F., 2009. Chitosan antitranspirant activity is due to abscisic acid-dependent stomatal closure. Environmental and Experimental Botany, vol. 66, no. 3, pp. 493-500. http://dx.doi.org/10.1016/j.envexpbot.2009.01.004.

JARDIN, P., 2015. Plant biostimulants: definition, concept, main categories and regulation. Scientia Horticulturae, vol. 196, pp. 3-14. https://doi.org/10.1016/j.scienta.2015.09.021.

KALAJI, M.H. and GUO, P. 2008. Chlorophyll fluorescence: a useful tool in barley plant breeding programs. In: A. Sanchez and S.J. Gutierrez, eds. Photochemistry research progress. USA: Nova Publishers, pp 439-463.

KAUR, S. and DHILLON, G.S., 2014. The versatile biopolymer chitosan: potential sources, evaluation of extraction methods and applications. Critical Reviews in Microbiology, vol. 40, no. 2, pp. 155-175. http://dx.doi.org/10.3109/1040841X.2013.770385. PMid:23488873.

KHAN, W.M., PRITHIVIRAJ, B. and SMITH, D.L., 2002. Effect of foliar application of chitin and chitosan oligosaccharides on photosynthesis of maize and soybean. Photosynthetica, vol. 40, no. 4, pp. 621-624. http://dx.doi.org/10.1023/A:1024320606812.

LIZÁRRAGA-PAULÍN, E.G., TORRES-PACHECO, I., MORENO-MARTINEZ, E. and MIRANDA-CASTRO, S.P., 2011. Chitosan application in maize (Zea mays) to counteract 
the effects of abiotic stress at seedling level. African Journal of Biotechnology, vol. 10, no. 34, pp. 6439-6446. http://dx.doi. org/10.5897/AJB10.1448.

MAGALHÃES, P.C. and DURÃES, F.M.O., 2008. Fisiologia da produção. In: J.C. Cruz, I.A. PEREIRA FILHO, R.C. ALVARENGA, M.M. GONTIJO NETO, M.F. OLIVEIRA and W.J.R. MATRANGOLO. A cultura do milho. Sete Lagoas: EMBRAPA Milho e Sorgo, pp. 63-87.

MALERBA, M. and CERANA, R., 2016. Chitosan effects on plant systems. International Journal of Molecular Sciences, vol. 17, no. 7, pp. 996-111. http://dx.doi.org/10.3390/ijms 17070996. PMid:27347928.

MARTINS, M., VERONEZE-JUNIOR, V., CARVALHO, M., CARVALHO, D.T., BARBOSA, S., DORIGUETTO, A.C., MAGALHAES, P.C., RIBEIRO, C., SANTOS, M.H. and SOUZA, T.C., 2018. Physicochemical characterization of chitosan and its effects on early growth, cell cycle and root anatomy of transgenic and non-transgenic maize hybrids. Australian Journal of Crop Science, vol. 12, no. 1, pp. 56-66. http://dx.doi.org/10.21475/ ajcs.18.12.01.pne649.

MONDAL, M.M.A., PUTEH, A.B., DAFADER, N.C., RAFII, M.Y. and MALEK, M.A., 2013. Foliar application of chitosan improves growth and yield in maize. Journal of Food Agriculture and Environment, vol. 11, no. 2, pp. 520-523.

NUCCIO, M.L., 2018. A brief history of promoter development for use in transgenic maize applications. In: L.M. Lagrimini, eds. Maize - methods in molecular biology. New York: Humana Press, Vol. 1676. http://dx.doi.org/10.1007/978-1-4939-7315-6_4.

PICHYANGKURA, R. and CHADCHAWAN, S., 2015. Biostimulant activity of chitosan in horticulture. Scientia Horticulturae, vol. 196, no. 1, pp. 49-65. http://dx.doi.org/10.1016/j.scienta.2015.09.031.

PONGPRAYOON, W., ROYTRAKUL, S., PICHAYANGKURA, R. and CHADCHAWAN, S., 2013. The role of hydrogen peroxide in chitosan-induced resistance to osmotic stress in rice (Oryza sativa L.). Plant Growth Regulation, vol. 70, no. 2, pp. 159-173. http:// dx.doi.org/10.1007/s10725-013-9789-4.

PRADO, S.A., CABRERA-BOSQUET, L., GRAU, A., COUPELLEDRU, A., MILLET, E.J., WELCKER, C. and TARDIEU, F., 2018. Phenomics allows identification of genomic regions affecting maize stomatal conductance with conditional effects of water deficit and evaporative demand. Plant, Cell \& Environment, vol. 41, no. 2, pp. 314-326. http://dx.doi.org/10.1111/pce.13083. PMid:29044609.

REIS, C.O., MAGALHÃES, P.C., AVILA, R.G., ALMEIDA, L.G., RABELO, V.M., CARVALHO, D.T., CABRAL, D.F., KARAM, D. and SOUZA, T.C., 2018. Action of N-Succinyl and N, O-dicarboxymethyl chitosan derivatives on chlorophyll photosynthesis and fluorescence in drought-sensitive maize. Journal of Plant Regulation, vol. 38, no. 2, pp. 619-630. https:// doi.org/10.1007/s00344-018-9877-9.

SAGLAM, A., KADIOGLU, A., DEMIRALAY, M. and TERZI, R., 2014. Leaf rolling reduces photosynthetic loss in maize under severe drought. Acta Botanica Croatica, vol. 73, no. 2, pp. 315-332. http://dx.doi.org/10.2478/botcro-2014-0012.
SHAFIQ, S., AKRAM, N.A. and ASHRAF, M., 2015. Does exogenously-applied trehalose alter oxidative defense system in the edible part of radish (Raphanus sativus L.) under water-deficit conditions? Scientia Horticulturae, vol. 185, pp. 68-75. http:// dx.doi.org/10.1016/j.scienta.2015.01.010.

SOUZA, T.C., CASTRO, E.M., MAGALHÃES, P. C, LINO, L. O., ALVES, E. T., and ALBUQUERQUE, P.E.P., 2013a. Morphophysiology, morphoanatomy, and grain yield under field conditions for two maize hybrids with contrasting response to drought stress. Acta Physiologiae Plantarum, vol. 35, no. 11, pp. 3201-3321. http://dx.doi.org/10.1007/s11738-013-1355-1.

SOUZA, T.C., CASTRO, E.M., MAGALHÃES, P.C., CASTRO, E.M., ALBUQUERQUE, P.E.P. and MARABESI, M.A., 2013b. The influence of ABA on water relation, photosynthesis parameters, and chlorophyll fluorescence under drought conditions in two maize hybrids with contrasting drought resistance. Acta Physiologiae Plantarum, vol. 35, no. 2, pp. 515-527. http://dx.doi.org/10.1007/ s11738-012-1093-9.

SOUZA, T.C., MAGALHÃES, P.C., CASTRO, E.M., CARNEIRO, N.P., PADILHA, F.A. and GOMES JÚNIOR, C.C., 2014. ABA application to maize hybrids contrasting for drought tolerance: changes in water parameters and in antioxidant enzyme activity. Plant Growth Regulation, vol. 73, no. 3, pp. 205-217. http://dx.doi. org/10.1007/s10725-013-9881-9.

SOUZA, T.C., MAGALHÃES, P.C., CASTRO, E.M., DUARTE, V.P. and LAVINSKY, A.O., 2016. Corn root morphoanatomy at different development stages and yield under water stress. Pesquisa Agropecuária Brasileira, vol. 51, no. 4, pp. 330-339. http://dx.doi. org/10.1590/S0100-204X2016000400005.

VAN KOOTEN, O. and SNEL, J., 1990. The use of chlorophyll fluorescence nomenclature in plant stress physiology. Photosynthesis Research, vol. 25, no. 3, pp. 147-150. http://dx.doi.org/10.1007/ BF00033156. PMid:24420345.

YAN, H., WU, L., FILARDO, F., YANG, X., ZHAO, X. and FU, D., 2017. Chemical and hydraulic signals regulate stomatal behavior and photosynthetic activity in maize during progressive drought. Acta Physiologiae Plantarum, vol. 39, no. 6, pp. 125. http://dx.doi.org/10.1007/s11738-017-2418-5.

YAN, W., ZHONG, Y. and SHANGGUAN, Z., 2016. Evaluation of physiological traits of summer maize under drought stress. Acta Agriculturae Scandinavica B - Soil \& Plant Science, vol. 66, no. 2, pp. 133-140. https://doi.org/10.1080/09064710.201 5.1083610

ZARGAR, V., ASGHARI, M. and DASHTI, A., 2015. A review on chitin and chitosan polymers: structure, chemistry, solubility, derivatives, and applications. ChemBioEng Reviews, vol. 2, no. 3, pp. 204-226. http://dx.doi.org/10.1002/cben.201400025.

ZHANG, X., LI, K., LIU, S., XING, R., YU, H., CHEN, X. and LI, P., 2016. Size effects of chitooligomers on the growth and photosynthetic characteristics of wheat seedlings. Carbohydrate Polymers, vol. 138, pp. 27-33. http://dx.doi.org/10.1016/j. carbpol.2015.11.050. PMid:26794734. 


\section{SUPPLEMENTARY MATERIAL}

Table S1 - Chemical characteristics of the soil used in the experiment.

\begin{tabular}{|c|c|c|c|c|c|c|c|c|c|c|c|c|}
\hline pH & $\begin{array}{c}\mathbf{P} \\
\text { (Mehlich) }\end{array}$ & $\mathbf{K}$ & $\mathrm{Ca}+2$ & $\mathrm{Mg}+2$ & $\mathbf{A l}+\mathbf{3}$ & SB* & $V^{*}$ & O.M* & Zn & $\mathrm{Fe}$ & Mn & $\mathrm{Cu}$ \\
\hline$(\mathrm{H} 2 \mathrm{U})$ & mg dm-3 & \multicolumn{5}{|c|}{------------mmolc dm-3------------ } & $\%$ & g dm--3 & \multicolumn{4}{|c|}{--------mg dm-3-------- } \\
\hline 5.2 & 5.0 & 1.9 & 32.0 & 11.0 & 0.0 & 44.9 & 62 & 32.0 & 1.1 & 29.0 & 8.1 & 1.5 \\
\hline
\end{tabular}

* Sum of bases (SB); base saturation index (V); organic matter (O.M.).



Figure S1. Maximum (Hum_Max) and minimum (Hum_min) relative air humidity and maximum (T_max) and minimum (T_Min) temperature throughout the days of the experiment.



Figure S2. Global radiation inside the greenhouse where the experiments were carried out. 